Thorax (1972), 27, 83.

\title{
Viability of fresh aortic valve homografts: a quantitative assessment
}

\author{
N. A L - J A N A B I, L. G O NZA LEZ - L A V I N ${ }^{1}$, \\ R. NEIROTTI, and D. N. ROSS \\ Department of Surgery, National Heart Hospital, London
}

\begin{abstract}
Accumulated evidence indicates that fresh aortic valve homografts function longer than preserved grafts. Thus it becomes important to assess the viability of fresh homografts on a quantitative basis. Recently, we have used autoradiography in addition to tissue culture to determine the viability of fresh aortic and pulmonary valve homografts. The uptake of thymidine was gradually reduced to $50 \%$ after 18 days of preservation in a balanced salt solution with antibiotics and the uptake was reduced to $21 \%$ in 63 days. We think that a nutrient medium is necessary if longer viability is to be obtained.
\end{abstract}

Aortic valve homografts have established themselves as one of the best substitutes for diseased valves (Gonzalez-Lavin and Ross, 1970; BarrattBoyes and Roche, 1969). Accumulated evidence indicates that fresh homograft valves continue to function 11 and 15 years after implantation (Jude, 1970), that their normal structure is maintained (Smith, 1967), and that the incidence of late degenerative changes up to five years has been minimal (Barratt-Boyes et al., 1969). It is logical to assume that when such a graft is implanted a longer function of the valve should be expected.

If, in addition, the valve is living, it should maintain its structure and consequently function for a long time. Thus it becomes important to assess the viability of fresh homografts on a quantitative basis. Angell, Mermet, and Buch (1970) have demonstrated by tissue culture that the homograft valve will retain some viable cells following sterilization with antibiotics and storage in Hank's solution at $4^{\circ} \mathrm{C}$. However, it is not possible by this method alone to determine the percentage of cells remaining viable.

Autoradiography, on the other hand, is an important method of assessing cellular metabolism and quantitating the percentage of living cells in a given tissue (Boyd, 1955; Gude, 1968).

Recently we have used autoradiography, in addition to tissue culture, to determine the viability of fresh homograft valves. The description of these two methods as applied to fresh homografts and a report of the initial result are the basis of this communication.

1Reprint requests to L. Gonzalez-Lavin, M.D.

\section{MATERIALS AND METHODS}

Eighteen aortic and four pulmonary valve homografts were collected under unsterile conditions within 48 hours of death. After dissection the valves were placed in Hank's solution to which antibiotics were added, following the method described by Barratt-Boyes and Roche (1969). Viability was determined after 24 and 72 hours, $2,3,6,8$, and 9 weeks of storage.

TISSUE CULTURE A modification of the organ culture technique of Paul (1965) using a liquid medium was used throughout. Petri dishes were prepared by scratching the base of the dish with a fine scalpel to provide a good irregular surface for tissue to attach to the dish. Fragments of the homograft arterial wall and leaflets were taken and placed on the Petri dishes. Four millilitres of medium 199 plus $10 \%$ calf serum (Burroughs-Wellcome) $)^{1}$ were added. The dishes were then placed in a plastic box, flushed gently with $5 \% \mathrm{CO}_{2}$ in air and incubated at $37^{\circ} \mathrm{C}$. The media was changed twice a week to allow nutrition of the tissue in culture. The Petri dishes were examined at regular intervals; growth was considered good if all pieces were adherent to the base of the dish.

AUTORADIOGRAPHY The method used is a modification of that described by Kopriwa and Leblond (1962). Two pieces of arterial wall and leaflets from the homograft were incubated at $37^{\circ} \mathrm{C}$ for 48 hours in nutrient solution 199. To this solution $10 \%$ of calf serum (Burroughs-Wellcome) and 5\% methyl tritiated thymidine were added.

After the period of incubation the tissues were washed twice with unlabelled nutrient medium at a

1Burroughs-Wellcome \& Co., Dartford, Kent 
two-hour interval to remove excess ${ }^{3} \mathrm{H}$-labelled medium. Next the labelled tissues were placed in $10 \%$ formalin and subjected to routine histological procedures. A thin film of emulsion (Ilford $\mathrm{K} 2$ nuclear emulsion $)^{2}$ was plated over the sections, allowed to dry, and then kept in 'light-tight' boxes at $5^{\circ} \mathrm{C}$ for seven days. The emulsion-covered sections were then developed with Ilford $1-19^{2}$ and fixed in Ilford $1-\mathrm{F}^{2}$ solution. Sections were stained with haematoxylin and eosin or Giemsa. To demonstrate elastic tissue a van Gieson counterstain was used. Microscopy and counting were performed as follows:

Twenty unspecified fields of $0.0202 \mathrm{~mm}^{2}$ were examined microscopically for (a) histological appearance, (b) number of fibroblasts labelled with methyl tritiated thymidine, and (c) number of unlabelled fibroblasts. The percentage of the labelled fibroblasts was calculated according to the following formula:

$$
\begin{aligned}
& \frac{\text { No. of labelled fibroblasts per field }}{\text { Total no of labelled and unlabelled }} \times 100=\% \\
& \text { Total no. of labelled and unlabelled } \times 100=\text { labelled } \\
& \text { fibroblasts per field } \\
& \text { fibroblasts }
\end{aligned}
$$

\section{RESULTS}

Thymidine uptake is considered a good index for viability of the cells, representing active cell meta-

¿IIford Ltd., Ilford, Essex bolism. Percentages of viability for the valves under study were obtained by taking a mean value of counts from 20 different fields. The results are best illustrated by a histogram (Fig. 1). There was

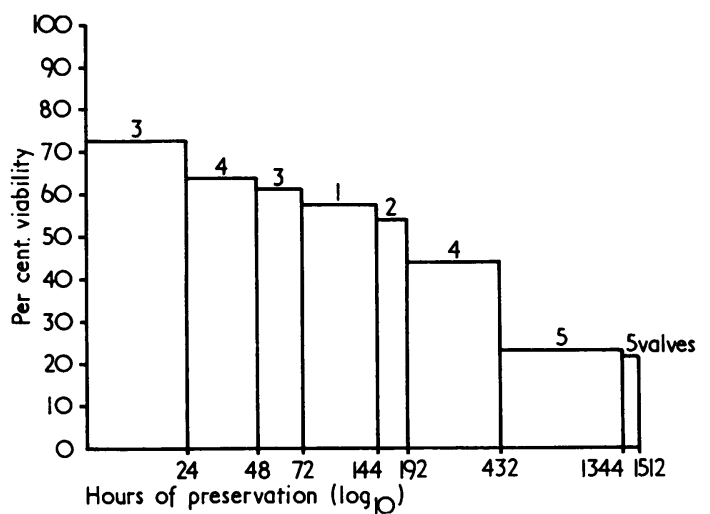

FIG. 1. The relationship between viability as assessed by autoradiography and length of preservation of homografts in Hank's solution containing antibiotics. The number at the top of each column refers to the number of valves studied.

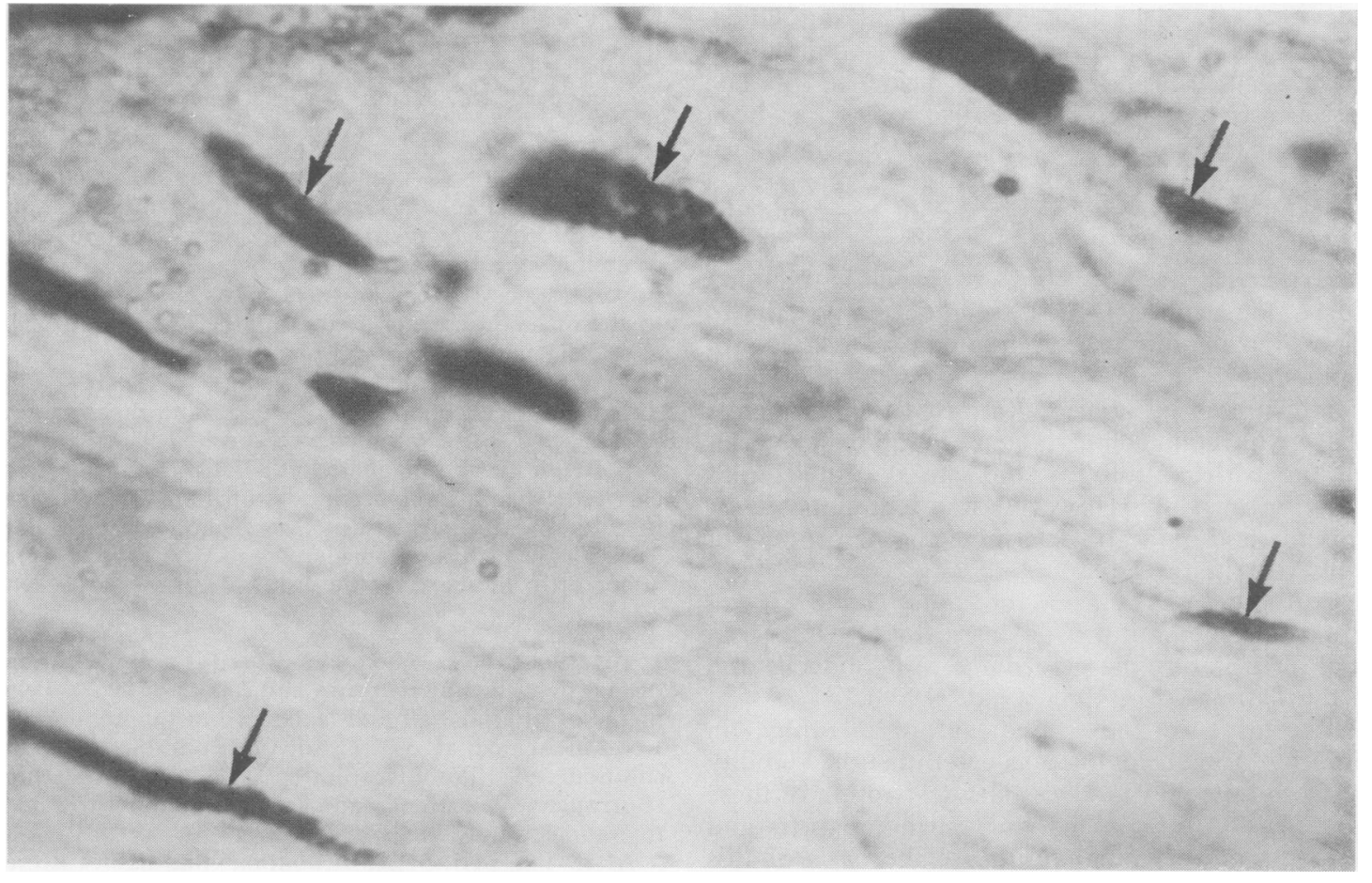

FIG. 2. Thin section of ${ }^{3} \mathrm{H}$-thymidine-treated aortic cusp preserved for 48 hours in Hank's solution and antibiotics show's a large number of grains associated with the nuclear regions. Haematoxylin and eosin $\times 2400$. 


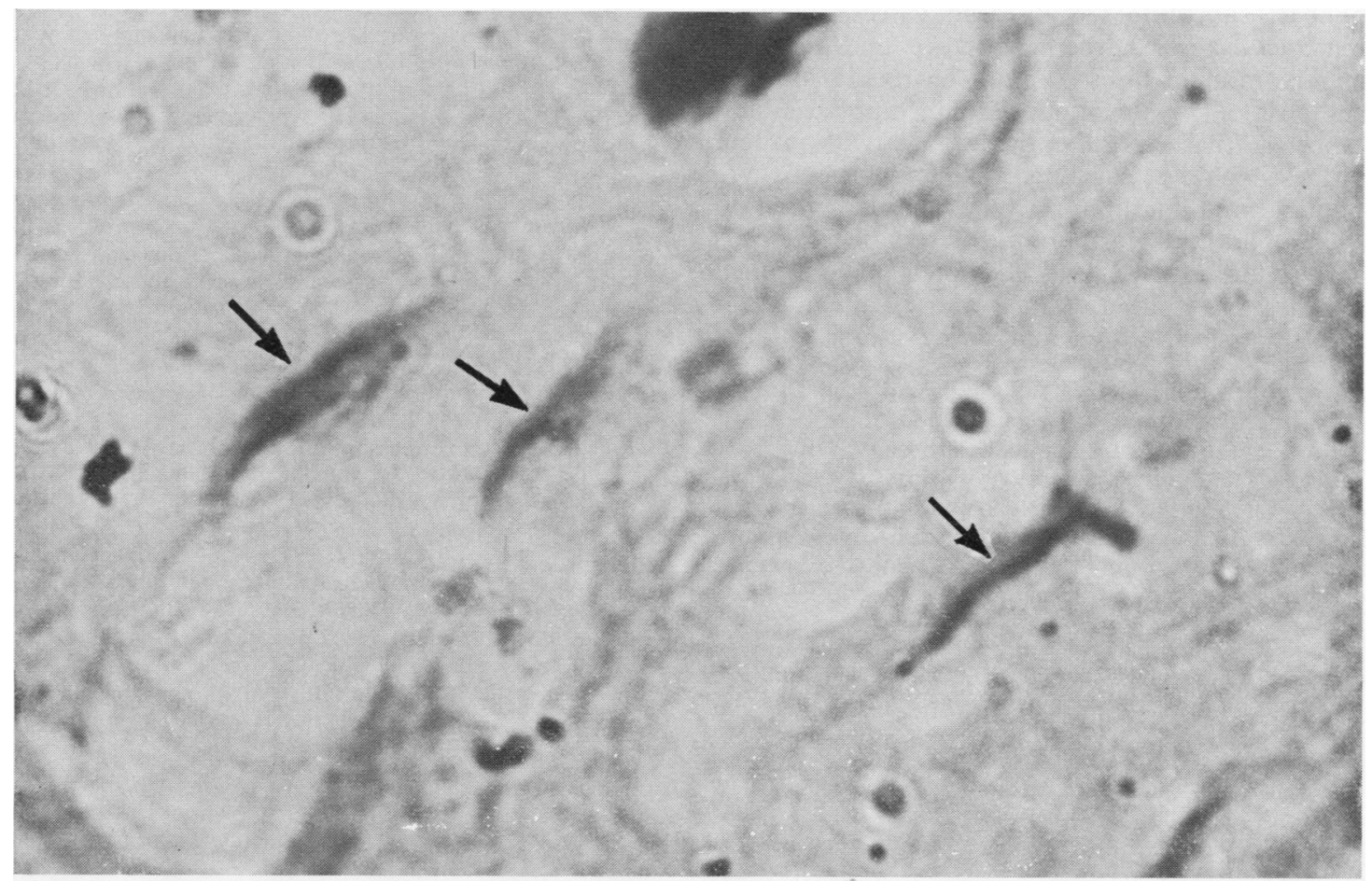

FIG. 3. Thin section of ${ }^{3} \mathrm{H}$-thymidine-treated aortic cusp preserved for nine weeks (1,512 hou's) in Hank's solution and antibiotics. There are a very small number of grains associated with the nuclear regions. Haeriatoxylin and eosin $\times 2400$.

a pronounced and steady fall in the thymidine uptake throughout the time of study.

Seventy-three per cent of the fibroblasts studied actually took thymidine during the first 24 hours (Fig. 2). This was regarded as a high uptake if one considers the time factor ( 48 hours after death) and the external influences that the homograft valves are subjected to before being placed in a balanced salt solution. The minimum uptake of thymidine was $21 \%$ (Fig. 3 ) recorded at 63 days (1,512 hours). Fibroblast growth by tissue culture was obtained in $70 \%$ of the valves during the first four weeks.

\section{DISCUSSION}

Antibiotic sterilization of homograft valves is at present considered to be one of the best methods available, as the structure of the graft is preserved, and permits a high percentage of cells to remain viable.

Autoradiography demonstrates the uptake and metabolism of radioactive substances within living cells. Tritium-labelled thymidine is incorporated into the desoxyribonucleic acid (DNA) of the nuclei in those cells preparing for division. The nuclei of these cells and those of their daughter cells will be labelled while those cells that are in other stages of the interface or are not viable will remain unlabelled.

This study shows a decrease in labelled cells from $73 \%$ at 24 hours to $21 \%$ after nine weeks of storage. It appears that the decline in active metabolic cells is faster during the first days of preservation and becomes slower after 18 days. This decline may be expected because the mode of preservation, Hank's solution, is not a nutrient medium and consequently there is a lack of protein synthesis with death of the cells.

Fresh homograft valves collected within 48 hours were found to have a high percentage of viable cells. This percentage could be even higher if collection were done within 12 to 24 hours.

After the eighteenth day of preservation in balanced salt solution (Hank's), radioactive uptake of thymidine had decreased to almost half of the initial number of cells and morphological alterations of the architecture of the graft began to appear. If one considers living homografts to be 
the best substitute for diseased valves, knowing that they preserve their structure and function longer, modifications should be made on the methods of preservation, adding nutritive substances so that a positive metabolism with protein synthesis could be sustained by the viable cells. We found autoradiography a very useful method to assess quantitatively the percentage of viable cells in fresh homografts; this method can be applied to heart valves at any stage during the time of collection, sterilization, and preservation.

The co-operation of Dr. J. Douglas, of the Biology Department of Brunel University, and Dr. A. P. Riley, of the Department of Chemical Pathology, University College of London University, is gratefully acknowledged. The authors also wish to thank Mrs. Margaret Birrell for her work in the preparation of the homografts and Miss Susan Thomas for technical assistance in the preparation of this paper.

\section{REFERENCES}

Angell, W. W., Mermet, B., and Buch, W. (1970). Antibiotic sterilization of fresh homograft valves. Circulation, 42, Suppl. III, p. 130 (Abstr.).
Barratt-Boyes, B. G., and Roche, A. H. G. (1969). A review of aortic valve homografts over a six and one-half year period. Ann. Surg., 170, 483.

- , Brandt, P. W. T., Smith, J. C., and Lowe, J. B. (1969). Aortic homograft replacement. A long-term follow-up of an initial series of 101 patients. Circulation, 40, 763.

Boyd, G. A. (1955). Autoradiography in Biology and Medicine. Academic Press, New York.

Gonzalez-Lavin, L., and Ross, D. (1970). Homograft aortic valve replacement. A five-year experience at the National Heart Hospital, London. J. thorac. cardiovasc., Surg., 60, 1.

Gude, W. D. (1968). Autoradiographic Techniques: Localization of Radioisotopes in Biological Material. PrenticeHall, Englewood Cliffs, New Jersey.

Jude, J. R. (1970). In discussion of Bahnson, H. T., Hardesty, R. L., Baker, L. D. Jr., Brooks, D. H., and Gall, D. A. Fabrication and evaluation of tissue leaflets for aortic and mitral valve replacement. Ann. Surg., 171, 939.

Kopriwa, B. M., and Leblond, C. P. (1962). Improvements in the coating technique of radioautography. J. Histochem. Cytochem., 10, 269.

Paul, J. (1965). Cell and Tissue Culture, 3rd ed. Livingstone: Edinburgh.

Smith, J. C. (1967). The pathology of human aortic valve homografts. Thorax, 22, 114. 